\title{
DEVELOPMENT AND PERFORMANCE EVALUATION OF GARLIC-CLOVES PLANTER
}

\section{Morad, M. M. ${ }^{1}$ M. M. A. El-Sharabasy ${ }^{2}$ I. Yehia $^{3}$ F. A. Abdelgawad ${ }^{4}$ ABSTRACT}

The aim of this investigation is to develop and evaluate a two rows garliccloves planter. The developed garlic-cloves planter consists of the main frame with three hitching-points, transmission system, furrow opener, covering device and two planting units. Each planting-unit consists of gloves hopper, agitator, cutoff, metering device, housing and metering device shaft. Laboratory experiments were carried out as a function of change in metering device speed, agitator speed, cutoff clearance and cloves size. While field experiments were conducted to optimize machine forward speed, the machine performance was studied in terms of cloves damage, plant scattering, emergency, crop yield, specific energy and planting cost.

The experimental results reveal that the garlic-cloves planter is recommended to be used under the following conditions:

- Metering-device speed of $20 \mathrm{rpm}(0.21 \mathrm{~m} / \mathrm{s})$ for all sizes of Chinese garlic cloves.

- Agitator speed of $50 \mathrm{rpm}(0.22 \mathrm{~m} / \mathrm{s})$ for all sizes of Chinese garlic-cloves.

- Cutoff clearance of $15 \mathrm{~mm}$ for all sizes of Chinese garlic-cloves.

- Planter forward speed of $3.44 \mathrm{~km} / \mathrm{h}$ for the medium clove size.

\section{INTRODUCTION}

arlic (Allium sativum L.) is a crop with a long history of plantation
in Egypt. The cultivated area of garlic crop in Egypt is 20.256
thousand feddans in 2009 producing about 175.743 thousand ton (Agric. Statistics Economic Affair Sector, 2009). Because of the high costs of the traditional methods of garlic planting, cultivation and harvesting which consuming more time and labor intensive, its large scale production is not economical and is therefore very limited. The academic and applied researches indicated that the drop in garlic yield, occurring through different stages of garlic production, is a vital problem to be solved.

\footnotetext{
${ }^{1}$ Prof. of Agric. Eng. Dept., Fac. of Agric., Zagazig Univ., Egypt. ${ }^{2}$ Assist. Prof. of Agric. Eng. Dept., Fac. of Agric., Zagazig Univ., Egypt. ${ }^{3}$ Head Researcher, Ag. Eng. Res. Inst., Agric. Res. Centre, Giza, Egypt. ${ }^{4}$ Eng. Res. Inst., Agric. Res. Centre, Giza, Egypt
} 
The academic and applied researches indicated that the drop in garlic yield, occurring through different stages of garlic production. Garlic crop is too sensitive to planting operation, due to the high percentage of non germinated cloves and non uniformity of cloves distribution affecting on the total yield. For this reason, such care had to be taken to design, develop and operate garlic planting machines with an accurate scientific guidance taking into consideration machine efficiency, cloves uniformity, energy and cost requirements. Rocha et al. (1991) designed a manually operated planter for garlic bulbs mounted on two bicycle wheels and equipped with a toothed belt distribution mechanism. In field tests with prototype equipment bulb were spaced at 5 bulbs/m. Harb and Abdel-Mawla (1997) developed a metering belt system garlic-planter to plant cloves at $10 \mathrm{~cm}$ spacings. Field experiments showed that machine planted cloves with more uniformity at low forward speeds. At high speed (above $3 \mathrm{~km} / \mathrm{h}$ ) the percentage of unsuccessful fed increased to more than $20 \%$, and accordingly, the mean number of cloves dropped per meter along the furrow decreased. Yehia (1997) and Awady et al. (2000) designed a garlic clove metering device with vertical wheel with groove device. They studied the effect of feeder speeds, groove shapes (rectangle, trapezoidal, and triangle), and groove widths on cloves discharge, damage and longitudinal cloves-distribution. They found that the groove width of $24 \mathrm{~mm}$, of a triangular shape and feeder speed of $20 \mathrm{rpm}$ had the best longitudinal cloves distribution. Jarudchai $\boldsymbol{e} t$ al. (2002) constructed and tested two models of garlic planters with different metering devices namely: (a) a vertical metering plate with triangular grooves and (b) a bucket type device. The bucket type metering device presented the most impressive results regarding uniformity of the metering system and low garlic clove damage of $0.23 \%$. The planter was attached to a $5 \mathrm{hp}$ power tiller and was tested in actual field conditions. The maximum forward speed was $2.63 \mathrm{~km} . \mathrm{h}^{-1}$ and planter wheel skid was high at about 23 $\%$. The planter field capacity was $0.73 \mathrm{fed} / \mathrm{h}$. El-Ashry (2004) modified a potato planting machine to suit garlic crop by replacing the original metering tray by adjustable one which has diameter of $40 \mathrm{~cm}$ and 14 cells, each cell cone have diameter of $7.0 \mathrm{~cm}$ at upper hole and $5.0 \mathrm{~cm}$ at lower hole. The field experiments were carried out under different machine forward speeds and planting spaces and their affecting on planting density, planting 
uniformity, field efficiency, required energy and total yield. The optimum values for the operation conditions were obtained at operating forward speed of $0.78 \mathrm{~km} / \mathrm{h}$ and planting space of $8.0 \mathrm{~cm}$. Helmy et al. (2005) modified and evaluated the feeding mechanism of the mechanical (Gaspardo) planter to plant garlic cloves under four levels of planting forward speeds and two speeds of planter speed ratio with three levels of seed hopper capacity. They found that the best limit of planting forward speed is between 1.5 and 2.5 $\mathrm{km} / \mathrm{h}$, planter speed ratio of 0.6 and seed hopper capacity is more than $50 \%$ of its capacity. Bakhtiari1 and Loghavi (2009) developed and evaluated an innovative garlic clove 3-row precision planter tractor-mounted. Seed metering-drum has three rows of 40 elliptical seed holes $(30 \times 20 \mathrm{~mm})$ for accommodating garlic clove. The performance parameters measured during the field tests included planting depth, seeding rate, seed spacing, miss index, multiple index and clove damage. They showed that the new machine was capable of planting 92400 plants/fed at the average clove placement depth and spacing of 12.3 and $22.7 \mathrm{~cm}$, respectively. Other performance parameters included miss and multiple indices of $12.3 \%$ and $2.43 \%$, respectively. El-Sharabasy and Ali (2011) developed and evaluated the planting unit of planter (Gaspardo) to be suitable for planting garlic cloves. This machine was evaluated to find out the optimum operating parameters for planting garlic cloves using versus nine different moving horizontal discs having three different cell diameters and three different disc thickness and four machine forward speeds. The obtained results revealed that the maximum plant emergency ratio of $97.10 \%$, the minimum missing hills of $5.1 \%$, the minimum longitudinal scattering of $0.48 \mathrm{~cm}$ and the maximum garlic yield of $8498 \mathrm{~kg} / \mathrm{fed}$ were recorded at lower machine forward speed of $1.17 \mathrm{~km} / \mathrm{h}$, cell diameter of $30 \mathrm{~mm}$ and disc thickness of $30 \mathrm{~mm}$.

\section{The objectives of this research were as following:}

- Development a tractor mounted precision planter capable of singulating and planting garlic cloves at predetermined depth, row and plant spacing.

- Optimizing through laboratory tests some different operating parameters, such as metering device speed, agitator speed and cutoff clearance affecting the performance of the developed machine.

- Optimizing, through field experiments, the machine forward speed.

- Evaluation the developed garlic planter from the economic point of view. 


\section{MATERIALS AND METHOD}

The main experiments were carried out on sandy soil through successive agricultural seasons of 2010 and 2011 at El-Kassassin Research. Station, Ismailia Governorate, Agricultural Research Center, Egypt, to test the developed garlic-cloves planter. The mechanical analysis of the experimental soil was $4.0 \%$ clay, $6.08 \%$ silt and $89.92 \%$ sand.

\section{(A) MATERIALS:}

1- The used crop: Garlic cloves Chinese variety was used in laboratory and field experiments. Table 1 shows the physical properties of Chinese garliccloves. These data were measured on 100 cloves sample, according to the standards set in (Mohsenin, 1986). Planting requires about $150 \mathrm{~kg} / \mathrm{fed}$ of cloves with rows spacing of about $60 \mathrm{~cm}$ and distance between cloves in the same row of about $10 \mathrm{~cm}$.

Table 1: Physical properties of garlic cloves of Chinese variety.

\begin{tabular}{|c|c|c|c|c|c|c|}
\hline $\begin{array}{l}\text { Cloves } \\
\text { Size }\end{array}$ & $\begin{array}{l}\text { Physical } \\
\text { properties }\end{array}$ & Max. & Min. & Average & S. D. ${ }^{(I)}$ & C. $V^{(2)}$ \\
\hline \multirow{3}{*}{ Large } & $\mathrm{L}, \mathrm{mm}$ & 40 & 35 & 36.8 & 1.67 & 4.54 \\
\hline & $\mathrm{W}, \mathrm{mm}$ & 30 & 21 & 25.2 & 2.16 & 8.56 \\
\hline & $\mathrm{T}, \mathrm{mm}$ & 21 & 9 & 15.2 & 3.30 & 21.69 \\
\hline \multirow{3}{*}{ Medium } & $\mathrm{L}, \mathrm{mm}$ & 34 & 30 & 31.9 & 1.27 & 4.00 \\
\hline & $\mathrm{W}, \mathrm{mm}$ & 27 & 21 & 24 & 1.65 & 6.87 \\
\hline & $\mathrm{T}, \mathrm{mm}$ & 17 & 8 & 13.0 & 2.29 & 17.55 \\
\hline \multirow{3}{*}{ Small } & $\mathrm{L}, \mathrm{mm}$ & 29 & 25 & 27 & 1.14 & 4.21 \\
\hline & $\mathrm{W}, \mathrm{mm}$ & 25 & 19 & 22 & 1.38 & 6.34 \\
\hline & $\mathrm{T}, \mathrm{mm}$ & 14 & 9 & 12 & 1.43 & 11.92 \\
\hline Large & \multirow{3}{*}{ Mass, $\mathrm{g}$} & 7 & 2.6 & 4.68 & 1.08 & 23.10 \\
\hline Medium & & 4 & 1.4 & 3.95 & 0.72 & 18.30 \\
\hline Small & & 2 & 0.8 & 1.52 & 0.31 & 20.14 \\
\hline Large & \multirow{3}{*}{ Volume, $\mathrm{cm}^{3}$} & 6.65 & 2.54 & 4.36 & 0.98 & 22.53 \\
\hline Medium & & 3.49 & 1.20 & 3.82 & 0.70 & 18.29 \\
\hline Small & & 2.22 & 0.76 & 1.36 & 0.32 & 23.16 \\
\hline Large & \multirow{3}{*}{$\mathrm{D}_{\mathrm{g}}, \mathrm{mm}$} & 29 & 21 & 42.03 & 2.33 & 9.70 \\
\hline Medium & & 23 & 18 & 21.46 & 1.44 & 6.71 \\
\hline Small & & 21 & 16 & 19.18 & 1.23 & 6.39 \\
\hline Large & \multirow{3}{*}{$\begin{array}{l}\text { Bulk density, } \\
\mathrm{g} / \mathrm{cm}^{3}\end{array}$} & & 0.52 & & - & - \\
\hline Medium & & & 0.54 & & - & - \\
\hline Small & & & 0.55 & & - & - \\
\hline Large & \multirow{3}{*}{$\begin{array}{l}\text { Real density, } \\
\mathrm{g} / \mathrm{cm}^{3}\end{array}$} & 1.15 & 0.99 & 1.22 & 0.07 & 5.39 \\
\hline Medium & & 1.17 & 0.92 & 1.61 & 0.11 & 6.53 \\
\hline Small & & 1.40 & 0.9 & 1.11 & 0.15 & 13.38 \\
\hline
\end{tabular}

(1) S. D. is standard deviation.

(2) C. V. is coefficient of variation. 
$\mathrm{L}, \mathrm{W}, \mathrm{T}$ are length, width and thickness, respectively and $\mathrm{D}_{\mathrm{g}}$ is geometric mean diameter.

2- The designed test-rig: The test-rig was designed specifically for this work and was constructed at a Research Institute, Agric. Res. Center. The views of the test-rig is shown in Fig. 1. The main parts of the test-rig are as follows:

- Frame: The frame is made of steel L-sections of $25 \times 2.5 \mathrm{~mm}$ with 207 $\mathrm{mm}$ length and $86 \mathrm{~mm}$ width. The frame is carried on four legs of 523 $\mathrm{mm}$ height. The planting unit was hinged to the frame by two bolts.

- Manual hand: The manual hand was connected with feeding shaft by a bolt to rotate feeding shaft manually.

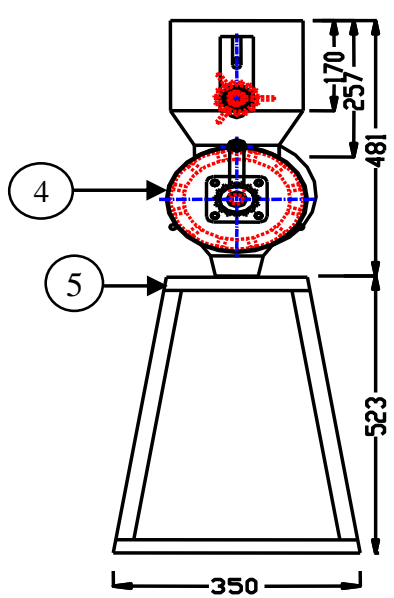

SIDE VIEW

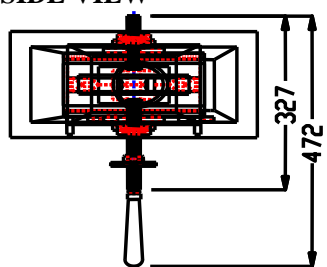

PLAN

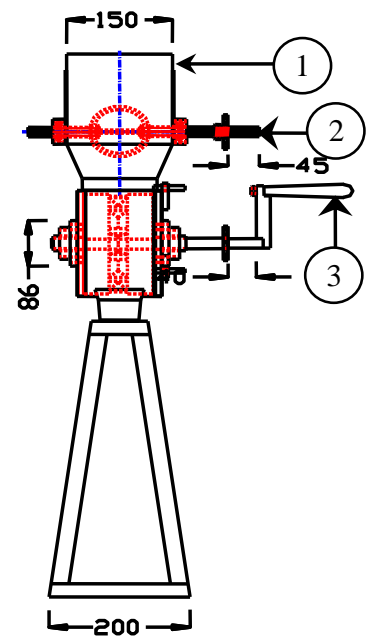

ELEVATION

\begin{tabular}{|c|c|c|}
\hline No. & Part name & No. off \\
\hline $\mathbf{1}$ & Cloves box & 1 \\
\hline $\mathbf{2}$ & Agitator & 1 \\
\hline $\mathbf{3}$ & Manual hand & 1 \\
\hline $\mathbf{4}$ & Metering device & 1 \\
\hline $\mathbf{5}$ & Frame & 1 \\
\hline
\end{tabular}

All Dims. in, mm.

\section{Fig. 1. The elevation, side view and plan for the test rig.}

3- The developed garlic-cloves planter: The developed garlic-cloves planter as shown in Fig. 2 consists of the main frame with the tool bar and three hitching-points, transmission system, two furrow openers, covering device and two planting units. The overall dimensions of the developed 
garlic-cloves planter are $150 \mathrm{~cm}$ length, $90 \mathrm{~cm}$ width and $110 \mathrm{~cm}$ height and its mass is about $205 \mathrm{~kg}$.

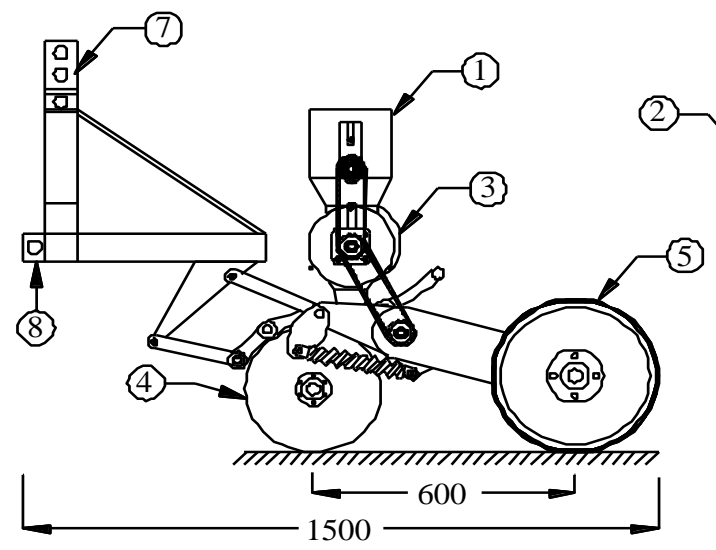

SIDE VIEW
ELEVATION

\begin{tabular}{|c|c|c|}
\hline No. & Part name & No. off \\
\hline 1 & Cloves box & 2 \\
2 & Agitator & 2 \\
3 & Metering device & 2 \\
4 & Double disc furrow opener & 2 \\
5 & Ground wheel & 2 \\
6 & Tool bar & 1 \\
7 & Upper hitching point & 3 \\
8 & Two lower hitching points & 2 \\
\hline
\end{tabular}

All Diminsionsin, mm

Fig. 2. Elevation and side view of the developed garlic cloves planter.

- Cloves hopper: The cloves hopper was built from sheet steel $2 \mathrm{~mm}$ thick, with dimensions of $188 \times 150 \times 235 \mathrm{~mm}$ and $62^{\circ}$ sloping bottom.

- The agitator: A crank agitator with 3-wings which designed by Yehia, (1997) was constructed to deliverer of garlic-cloves is activated by the agitator. The agitators were fixed inside the cloves hoppers and operated by means of sprockets and chains powered from the ground wheel.

- Cutoff: The cutoff was made of rubber with $19 \mathrm{~mm}$ thickness, $122 \mathrm{~mm}$ length and $100 \mathrm{~mm}$ width. The cutoff has a rectangular gate in the middle with different dimensions according to cloves size. The cutoff is fixed on the top of metering device and the bottom of hopper by two long bolts passed 
across the two sides of the hopper. Three gates were tested for three garlic cloves grades as shown in Table 2.

Table 2: Tested gates for three garlic cloves grades.

\begin{tabular}{cccc}
\hline \multirow{2}{*}{ Cutoff dimensions } & \multicolumn{3}{c}{ Cloves grade } \\
\cline { 2 - 4 } & Small & Medium & Large \\
\hline Length, mm & 37 & 39.5 & 44 \\
Width, mm & 31 & 33 & 35 \\
\hline
\end{tabular}

- Housing: The housing of metering device was made of sheet steel $2 \mathrm{~mm}$ thick, with dimensions of $96 \mathrm{~mm}$ width, $200 \mathrm{~mm}$ rear diameter and $213 \mathrm{~mm}$ front diameter. Two flanges (sides) with diameter of $200 \mathrm{~mm}$ and thickness of $8 \mathrm{~mm}$ are bolted with the two sides of the housing to support the metering device shaft by two bearings. A funnel is welded in the bottom of the housing and bolted with upper the clove tube (on the frame of planting unit) which exists between two discs of furrow opener.

- Metering-device: A vertical-axis metering-wheel with triangles grooves (designed by Yehia, 1997) was developed according to seed physical and mechanical properties (Fig. 3). The grooves on metering wheel were located at the periphery. Cloves are picked up by each groove from the hopper and dropped into the seed tube.

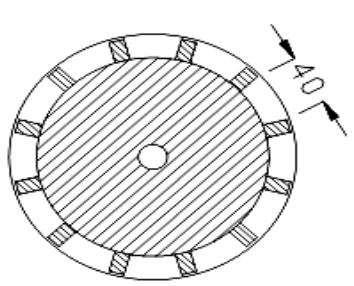

Section $A-A$

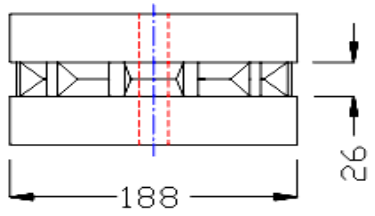

Plan
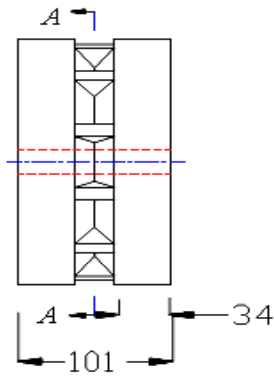

Elevation

Fig. (3): Metering device of garlic-cloves.

The designed and tested grooves dimensions for three sizes (classes or grades) of Chinese garlic cloves were shown in Table 3. 
Table 3: Grooves dimensions for three sizes of Chinese garlic cloves.

\begin{tabular}{ccccc}
\hline \multirow{2}{*}{ Cloves size } & \multirow{2}{*}{ Groove number } & \multicolumn{3}{c}{ Groove dimensions, cm } \\
\cline { 3 - 5 } & & Length & Width & Depth \\
\hline Small & 13 & 3.0 & 2.0 & 2.0 \\
Medium & 12 & 3.5 & 2.5 & 2.5 \\
Large & 11 & 4.5 & 3.3 & 3.0 \\
\hline
\end{tabular}

- Metering-device shaft: A shaft of $300 \mathrm{~mm}$ length and $20 \mathrm{~mm}$ diameter is connected to the metering-device housing by two ball bearings which bolted with two flanges. The metering device was interference with the feed shaft.

- Planting unit frame: The frame of planting unit, made of antimony material with total dimensions of $1040 \mathrm{~mm}$ length, $194 \mathrm{~mm}$ width $330 \mathrm{~mm}$ height which was taken from scrapped John Deere planter set in the developed garlic-clove planter.

- Furrow opener: A V-double discs furrow opener made of steel, had 310 $\mathrm{mm}$ diameter, $6 \mathrm{~mm}$ thickness and angle between discs of 9 degree which were taken from scraped John Deere planter were set in the developed garlicclove planter.

- Covering device: Zero pressure ribbed rubber soft center press-wheel with diameter of $400 \mathrm{~mm}$ and width of $100 \mathrm{~mm}$ which was taken from scraped John Deere planter set in the developed garlic-clove planter. The motion was transmitted to the metering device from press wheel by chains and sprockets.

- Transmission system: Transmission system consists of chains and sprockets. The transmission ratio between drive wheel (covering wheel) and metering-device shaft is $1: 1.16$.

4. Tractor: Nasr tractor of $50 \mathrm{~kW}$ (68 hp) was used for operating the planter. (B) METHOD:

Laboratory as well as field tests were carried out to study the effect of operating parameters on garlic-cloves planter performance.

1. Laboratory tests: The laboratory experiments were conducted under the following parameters:

- Metering-device speed: Six metering-device speeds of 10, 20, 30, 40, 50 and 60 r.p.m $(0.10,0.21,0.31,0.42,0.52$ and $0.63 \mathrm{~m} / \mathrm{s})$ corresponding to ground-wheel speeds of $9,17,26,34,43$ and 52 r.p.m $(0.21,0.36,0.54$, $0.71,0.90$ and $1.26 \mathrm{~m} / \mathrm{s})$. 
- Agitator speed: Six agitator speeds of 10, 20, 30, 40, 50 and 60 r.p.m $(0.04,0.09,0.13,0.18,0.22$ and $0.27 \mathrm{~m} / \mathrm{s})$.

- Cutoff clearance: Four cutoff clearances of zero, 10, 15 and $20 \mathrm{~mm}$.

- Cloves size: Three cloves-sizes (categories) of 25 - 29, 30 - 34 and 35 - 40 $\mathrm{mm}$.

To optimize the laboratory parameters, the following indicators were taken into consideration:

- Cloves discharge: The fed cloves were collected in plastic bag during a certain number of feeding-shaft revolutions to estimate cloves discharge under the previously mentioned factors.

- Cloves damage: For the previously-mentioned factors, the visible damage of cloves after passing through the metering device was calculated by the following equations (Yehia, 1993):

$$
\text { Visible cloves damage, } \%=\frac{\text { No.of damaged cloves }}{\text { TotalNo.of cloves }} \times 100
$$

2. Field experiments: The field experiments were carried out to optimize the following parameters:

- Four forward speeds of 1.40, 2.38, 3.44 and $4.73 \mathrm{~km} / \mathrm{h}$ (metering-device speeds of 22, 43, 53 and $73 \mathrm{rpm}$ and ground-wheel speeds of 25, 50, 62 and $85 \mathrm{rpm})$.

- Cutoff clearance of zero and $15 \mathrm{~mm}$.

Medium clove-size of $30-34 \mathrm{~mm}$ was used during the field experiments.

To optimize the field parameters, the following indicators were taken into consideration:

- Plant scattering: Plant scattering represents the overall difference between the actual and nominal cloves spacing in a percentage along a randomly selected $5 \mathrm{~m}$ length of each planted row. That is:

$$
C V \%=\frac{\sum\left(D-L_{1}\right)+\left(D-L_{2}\right)+\ldots \ldots .+\left(D-L_{n}\right)}{n \times D} \times 100
$$

Where: $\mathrm{CV}=$ Coefficient of Variation, $\mathrm{D}=$ Nominal cloves spacing $(\mathrm{cm})$, $\mathrm{L}=$ Actual cloves spacing $(\mathrm{cm})$ and $\mathrm{n}=$ Total number of cloves in spacing measured.

- Missing hills and double plants: Missing hills and double plants were calculated according to the following equations: 


$$
\begin{aligned}
& \text { Missing hills }=\frac{\text { Number of missing cloves in meter }}{\text { Number of adjusted cloves in meter }} \times 100 \\
& \text { Double plants }=\frac{\text { Number of double cloves in meter }}{\text { Number of adjusted cloves in meter }} \times 100
\end{aligned}
$$

- Emergence ratio: The number of plantings per meter of the row was counted to determine emergence ratio according to the following formula:

$$
\text { Emergence ratio }=\frac{\text { Average plant No.permeter }}{\text { Average No.of delivered cloves permeter }} \times 100
$$

- Final garlic-yield: Two rows of garlic crop with 3-m length for each forward speed were harvested by manual tool and weighed by analog balance to determine total yield, cloves yield and bulbs yield.

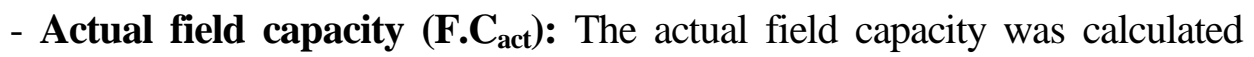
using the following equation:

$$
\text { F.C }_{{ }_{\text {act }}}=\frac{1}{\mathrm{~T}} \mathrm{fed} / \mathrm{h}
$$

Where: $\mathrm{T}_{\mathrm{t}}=$ Actual time consumed for planting one feddan, $\mathrm{h} / \mathrm{fed}$.

- Field efficiency $\left(\boldsymbol{\eta}_{\mathrm{f}}\right)$ : Field efficiency was calculated using the following equation:

$$
\eta_{\mathrm{f}}=\frac{\text { F.C. }_{\cdot_{\text {act }}}}{\text { F.C }_{\text {th }}} \times 100
$$

Where: $\eta_{\mathrm{f}}=$ Filed efficiency, $\%$,

F.C.act. $=$ Effective field capacity, fed/h.

F.C.th. $=$ Theoretical field capacity, fed./h.

- Slip of ground (press) wheel: Slippage percentage was calculated by using the following equation (Awady, 1992).

$$
\text { Slippage, } \%=\frac{\text { Actualdistance }- \text { Theoretical distance }}{\text { Theoretical distance }} \times 100
$$

Theoretical distance $=$ No. of wheel revolutions $\times \pi \times$ wheel diameter

- Fuel consumption: Was determined by accurately measuring the decrease in fuel level in the fuel tank immediately after executing each operation. 
- Required power: Was calculated by using the following formula (Hunt, 1983):

$$
\mathrm{Po}=\mathrm{F}_{\mathrm{c}} \times \mathrm{F}_{\mathrm{d}} \times\left(\frac{1}{3600}\right) \times \mathrm{C} . \mathrm{V} . \times 4270 \times \eta_{\mathrm{th}} \times \eta_{\mathrm{m}}
$$

Where: $\mathrm{Po}=$ Power requirements $(\mathrm{kW})$.

$F_{c}=$ The fuel consumption $(1 / h)$.

$\mathrm{F}_{\mathrm{d}}=$ Density of fuel $(\mathrm{kg} / \mathrm{l})$.

C.V. = Calorific value of fuel $(\mathrm{kcal} / \mathrm{kg})$.

$\eta_{\mathrm{th}}=$ Thermal efficiency of fuel. $\eta_{\mathrm{m}}=$ Mechanical efficiency of fuel.

- Specific energy: Specific energy can be calculated by using the following equation:

$$
\text { Specific energy }(\mathrm{kW} . \mathrm{h} / \text { fed. })=\frac{\text { Power required }(\mathrm{kW})}{\text { Actualfield capacity }(\mathrm{fed} / \mathrm{h})}
$$

- Cost analysis: The hourly cost was calculated according to equation of (Awady, 1978) in the following form:

$$
\mathrm{C}=\frac{\mathrm{P}}{\mathrm{h}}\left(\frac{1}{\mathrm{a}}+\frac{\mathrm{i}}{2}+\mathrm{t}+\mathrm{r}\right)+(1.2 \text { w.s.f })+\frac{\mathrm{m}}{144}, \quad \text { L.E } / \mathrm{h}
$$

Where:

$\mathrm{C}=$ Hourly cost, $\mathrm{L} . \mathrm{E} / \mathrm{h} . \quad \mathrm{P}=$ Price of machine, L.E.

$\mathrm{h}=$ Yearly working hours, $\mathrm{h} /$ year. $\mathrm{a}=$ Life expectancy of the machine, year.

$\mathrm{i}=$ Interest rate/year.

$\mathrm{F}=$ Fuel price, L.E/l.

$\mathrm{t}=$ Taxes, over heads ratio.

$\mathrm{r}=$ Repairs and maintenance ratio.

$\mathrm{m}=$ Monthly average wage, $\mathrm{L} . \mathrm{E} \quad 1.2=$ Factor accounting for lubrications.

$\mathrm{W}=$ Engine power, hp.

$\mathrm{S}=$ Specific fuel consumption, $\mathrm{l} / \mathrm{hp} . \mathrm{h}$.

$144=$ Reasonable estimation of monthly working hours .

Operational cost can be determined using the following equation:

$$
\text { Operational cost }=\frac{\text { Hourly cost }(\mathrm{L} . \mathrm{E} / \mathrm{h})}{\text { Effective field capacity }(\mathrm{fed} / \mathrm{h})}, \quad(\mathrm{L} . \mathrm{E} / \mathrm{fed})
$$

Cost per unit of production can be determined using the following equation:

$$
\text { Cost perunit of production }=\frac{\text { Operationalcost }(\mathrm{L} . \mathrm{E} / \mathrm{fed})}{\operatorname{Crop} \mathrm{y} \text { ield }(\mathrm{Mg} / \mathrm{fed})},(\mathrm{L} . \mathrm{E} / \mathrm{Mg})
$$




\section{RESULTS AND DISCUSSION}

The discussion will cover the obtained results under the following heads:

\section{- Results of laboratory experiments:}

\section{Effect of some different metering device parameters on garlic cloves discharge:}

Representative discharge values versus metering device speed are given for the three sizes of garlic cloves through various agitator speeds in Fig. 4. Data obtained show that increasing metering device speed from 10 to $60 \mathrm{rpm}$, measured for various agitator speeds of 10, 20, 30, 40, 50 and $60 \mathrm{rpm}$, decreased cloves discharge from 79.2 to 47.7 , from 111.8 to 76.6 , from 115.5 to 78.8 , from 121.4 to 82.1 , from 124.1 to 85.6 and from 125.3 to $85.8 \mathrm{~kg} / \mathrm{fed}$ for small cloves size; from 187.8 to 134.6 , from 220.6 to 165.2 , from 227.9 to 168.5 , from 235.5 to 171.3 , from 244.8 to 173.8 and from 245.6 to174.3 $\mathrm{kg}$ /fed for medium cloves size and from 163.4 to 127.8 , from 193.0 to 162.6, from 212.6 to 167.2 , from 246.7 to 171.4 , from 256.5 to 173.8 and from 257.1 to $175.2 \mathrm{~kg} /$ fed for large cloves size at constant cutoff clearance of 15 $\mathrm{mm}$. The same trend was noticed under the other cutoff clearances of zero, 10 and $20 \mathrm{~mm}$. The decrease in garlic cloves discharge by increasing metering device speed is because the increase in speed means not enough time to fill all metering device grooves by garlic cloves resulting in low cloves discharge. The increase in cloves discharge by increasing agitator speed may be due the increase in cloves numbers which are pushed by crank wings of agitator to the metering device grooves. The increase in cloves discharge by increasing cutoff clearance is attributed to more free space for each cell resulting high flow and good dropping of cloves in the metering device grooves.

\section{Effect of some different metering device parameters on garlic cloves damage:}

Representative damage values versus metering device speed are given for the three sizes of garlic cloves through various agitator speeds in Fig. 5. Data obtained show that increasing metering device speed from 10 to $20 \mathrm{rpm}$, measured for various agitator speeds of 10, 20, 30, 40, 50 and $60 \mathrm{rpm}$, decreased cloves damage from 4.8 to 4.3 , from 4.2 to 4.0 , from 3.8 to 3.5 , from3.6 to 3.1, from 3.1 to 2.5 and from 3.5 to $3.1 \%$ for small cloves size; 


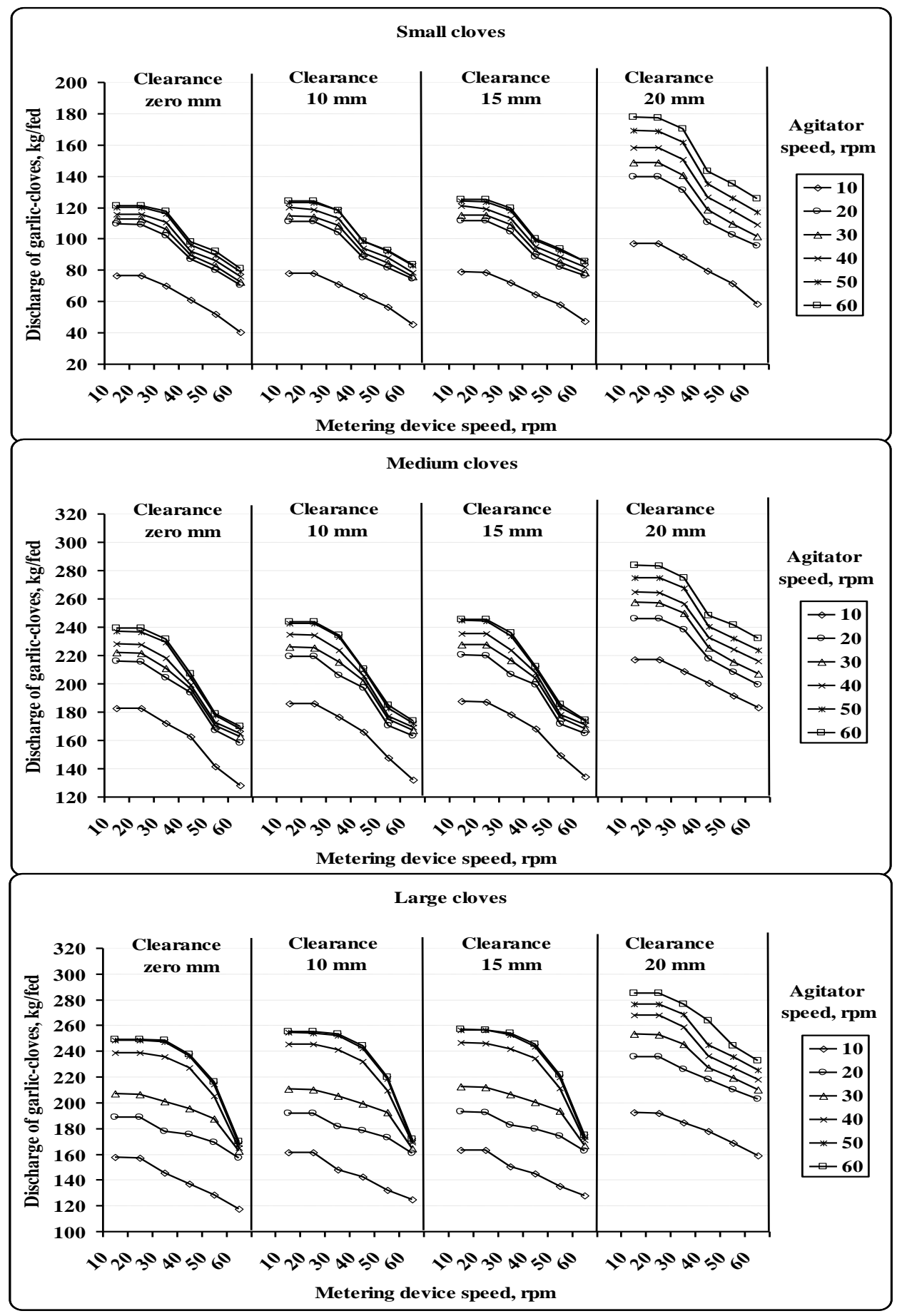

Fig. 4. Effect of metering-device speed, agitator speed and cutoff clearance on discharge of garlic-cloves. 


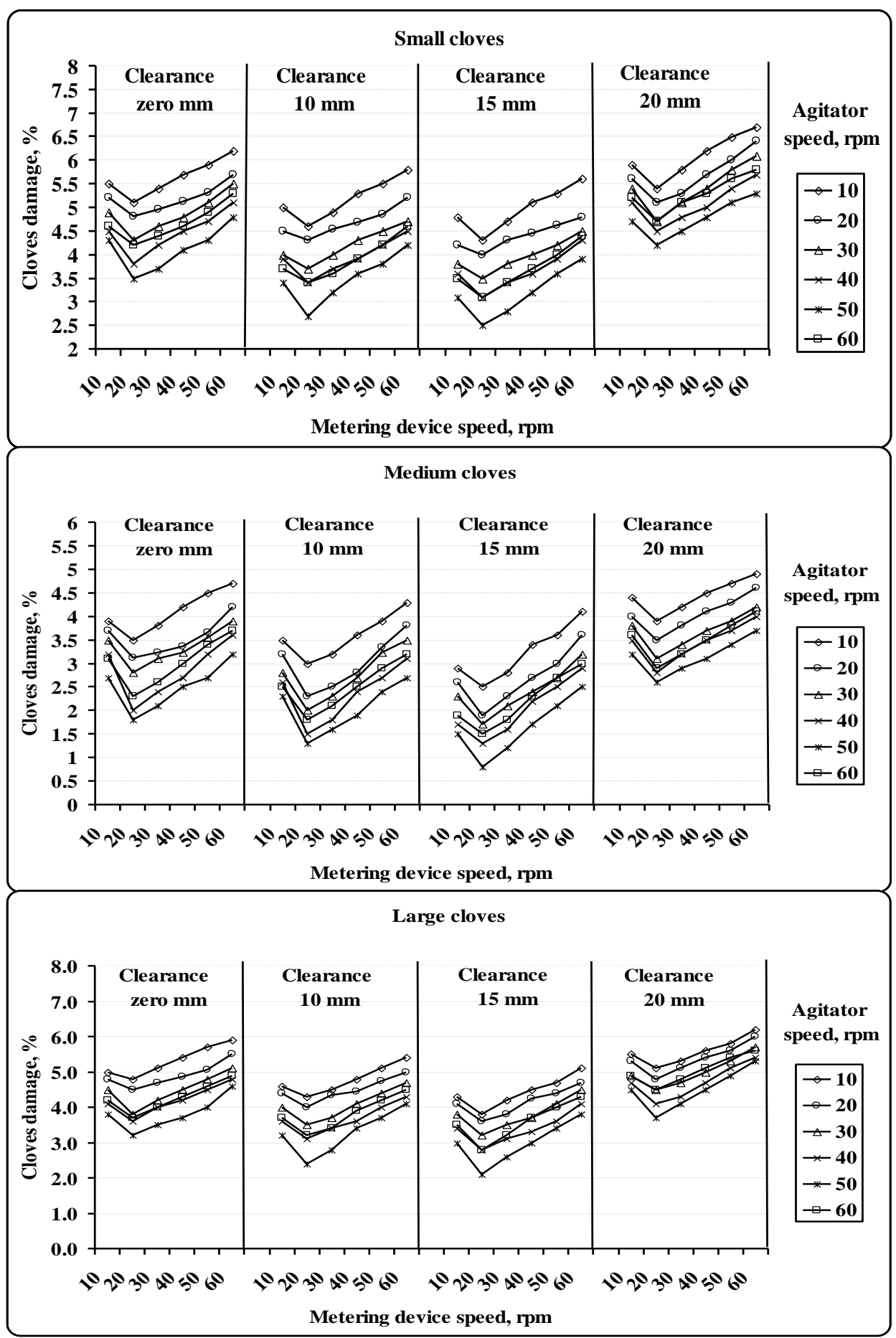

Fig. 5. Effect of metering-device speed, agitator speed and cutoff clearance on damage garlic-cloves. 
from 2.9 to 2.5 , from 2.6 to 1.9 , from 2.3 to 1.7 , from 1.7 to 1.3 , from 1.5 to 0.8 and from 1.9 to $1.5 \%$ for medium cloves size and from 4.3 to 3.8 , from 4.1 to 3.6 , from 3.8 to 3.2 , from 3.4 to 2.8 , from 3.0 to 2.1 and from 3.5 to 2.8 $\%$ for large cloves size at constant cutoff clearance of $15 \mathrm{~mm}$.

The same trend was noticed under the other cutoff clearances of zero, 10 and $20 \mathrm{~mm}$. The increase in garlic cloves damage at metering device speed of 10 rpm is due to increasing cloves jamming between metering device surface and the edges of agitator wings. The increase in garlic cloves damage by increasing metering device speed from 20 to $60 \mathrm{rpm}$ is due to increasing momentum of cloves. The decrease in cloves damage by increasing agitator speed from 10 to $50 \mathrm{rpm}$ may be due to decreasing the clove jamming and accumulation between agitator wings and metering device surface. The increase of cloves damage at agitator speed of $60 \mathrm{rpm}$ may be due to entering of two cloves (in vertical location) in the same groove of metering device. The decrease in cloves damage by increasing cutoff clearance from zero to $15 \mathrm{~mm}$ is due to decreasing the impact between clove dropped in metering device groove and the wall of cutoff hole in direction of cloves dropping from metering device (above double disc furrow opener). The increase in cloves damage at cutoff clearance of $20 \mathrm{~mm}$ is due to increasing cloves jamming between metering device surface and the bottom surface of cutoff.

\section{- Results of field experiments:}

\section{Effect of forward speed and cutoff clearance on cloves emergence:}

Fig. 6. shows the effect of forward speed on garlic-plant emergence. The garlic-plant emergence decreased with increasing forward speed from 1.40 to $4.73 \mathrm{~km} / \mathrm{h}$ and increased by increasing cutoff clearance from zero to $15 \mathrm{~mm}$. The maximum garlic-plant emergence of $99.81 \%$ was obtained with forward speed of $1.40 \mathrm{~km} / \mathrm{h}$ and cutoff clearance of $15 \mathrm{~mm}$. Meanwhile the minimum garlic-plant emergence of $98.05 \%$ was obtained with forward speed of 4.73 $\mathrm{km} / \mathrm{h}$ and cutoff clearance of zero $\mathrm{mm}$. The decrease of garlic-plant emergence by increasing forward speed is due to the increase of metering device speed and the momentum of cloves which causes cloves damage accordingly. Added to that, the depth of planting could not be thoroughly adjusted at high speed that tends to decrease plant emergence. Meanwhile, the increase of garlic-plant emergence by increasing cutoff clearance is due to decreasing the clogging of cloves under the metering device. 


\section{Effect of forward speed and cutoff clearance on plant scattering:}

The plants distribution was analyzed in order to determine the coefficient of variation $(\mathrm{CV})$ of garlic-plant spacing. A low $\mathrm{CV}$ represents a row with more uniform seed spacing, while the vice versa was noticed with high values of $\mathrm{CV}$. The plant scattering for different cutoff clearances and forward speeds were illustrated in Fig. 7. The optimum conditions clarify that the forward speed of $3.44 \mathrm{~km}$ and cutoff clearance of $15 \mathrm{~mm}$ had the best longitudinal cloves distribution (CV of $19.6 \%$ ). The increase of plant scattering by increasing forward speed may be due to increasing ground-wheel slip. Whereas, the decrease of plant scattering by increasing cutoff clearance may be due to increasing cloves discharge.

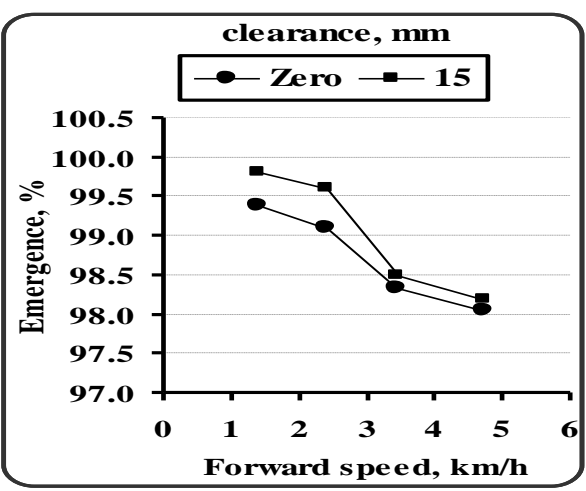

Fig. 6. Effect of forward speed and cutoff clearance on garlicplant emergence.

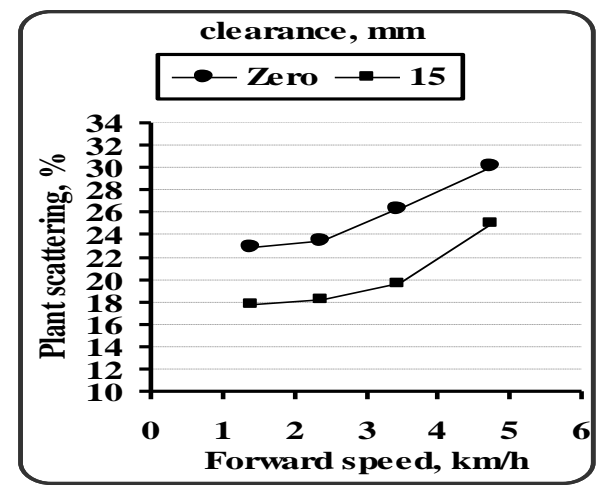

Fig. 7. Effect of forward speed and cutoff clearance on garlicplant scattering.

\section{Effect of forward speed and cutoff clearance on missing hills and double plants:}

Figs. 8 and 9. show the effect of forward speed on missing hills and double plants. Missing hills increased with increasing forward speed and decreased by increasing cutoff clearance. Results show that increasing forward speed from 1.40 to $4.73 \mathrm{~km} / \mathrm{h}$, increased missing hills from 0.2 to $1.8 \%$ at constant cutoff clearance of $15 \mathrm{~mm}$. Double plants decreased with increasing forward speed and increased by increasing cutoff clearance from zero to $15 \mathrm{~mm}$. Results show that increasing forward speed from 1.40 to $4.73 \mathrm{~km} / \mathrm{h}$, decreased double plants from 20.6 to $6.6 \%$ at constant cutoff clearance of 15 $\mathrm{mm}$. The increase of missing hills by increasing forward speed may be due to increasing ground wheel slip. Whereas, increasing double-cloves percent by increasing cutoff clearance may be due to increasing cloves discharge. 


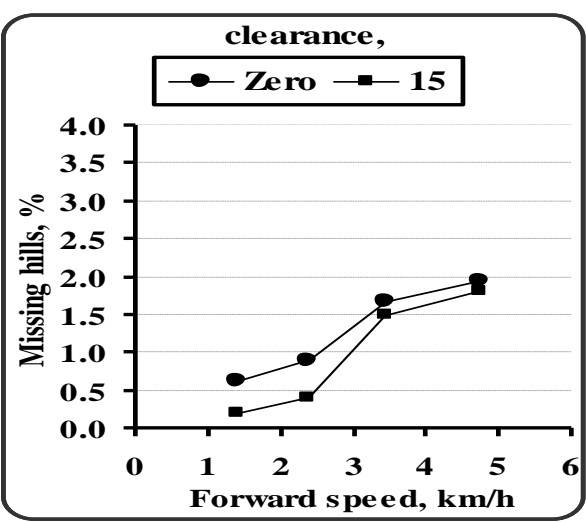

Fig. (8): Effect of forward speed and cutoff clearance on missing hills.

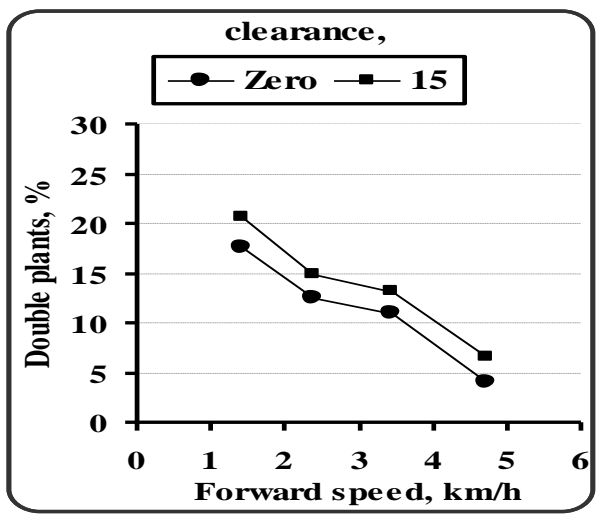

Fig. (9): Effect of forward speed and cutoff clearance on double plants.

\section{Effect of forward speed on final garlic yield:}

Fig. 10. shows the effect of forward speed and cutoff clearance on total yield, cloves yield and bulbs yield. Total yield decreased with increasing forward speed and increased by increasing cutoff clearance. Cloves yield and bulb yield increased with increasing forward speed and increased by increasing cutoff clearance. The maximum total yield of $7.2 \mathrm{Mg} / \mathrm{fed}$ was obtained with forward speed of $1.40 \mathrm{~km} / \mathrm{h}$ and cutoff clearance of $15 \mathrm{~mm}$. Meanwhile the minimum total yield of 4.07 ton/fed was obtained with forward speed of $4.73 \mathrm{~km} / \mathrm{h}$ and cutoff clearance of zero $\mathrm{mm}$. The decrease in total yield by increasing forward speed is due to the low plant emergence resulting from ground wheel slip at high speed. Also due to cloves damage occurred by the effect of the planting device. The maximum cloves yield and bulbs yield of $2.42 \mathrm{Mg} / \mathrm{fed}$ and $2.50 \mathrm{Mg} / \mathrm{fed}$ was obtained with forward speed of $3.44 \mathrm{~km} / \mathrm{h}$ and cutoff clearance of $15 \mathrm{~mm}$. Meanwhile the minimum cloves yield and bulbs yield of $1.44 \mathrm{Mg} / \mathrm{fed}$ and $1.52 \mathrm{Mg} / \mathrm{fed}$ was obtained with forward speed of $1.40 \mathrm{~km} / \mathrm{h}$ and cutoff clearance of zero $\mathrm{mm}$.

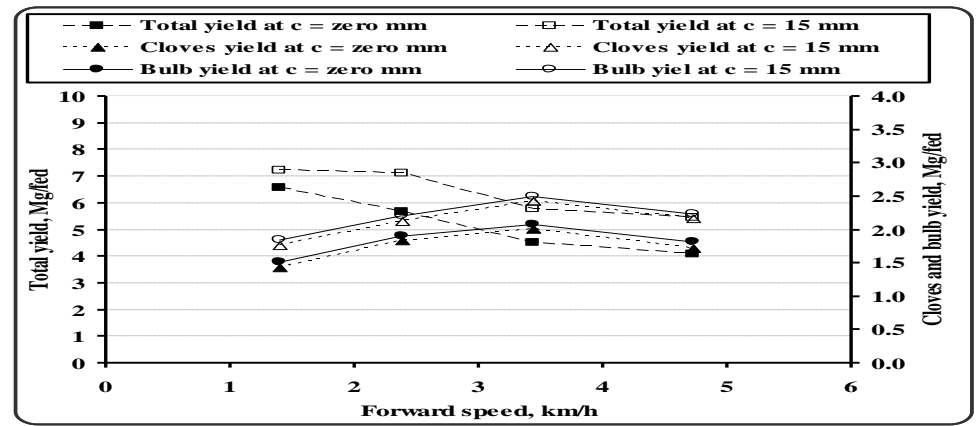

Fig. 10. Effect of forward speed and cutoff clearance on total yield, cloves yield and bulbs yield. 


\section{Effect of forward speed on machine field capacity, efficiency and wheel slip:}

Fig. 11. shows the effect of forward speed on actual field-capacity, field efficiency and slip percent. The maximum actual field capacity of $1.03 \mathrm{fed} / \mathrm{h}$ was obtained with forward speed of $4.73 \mathrm{~km} / \mathrm{h}$. Meanwhile, the minimum actual field capacity of $0.37 \mathrm{fed} / \mathrm{h}$ was obtained with forward speed of 1.40 $\mathrm{km} / \mathrm{h}$. The maximum field-efficiency of $93.22 \%$ was obtained with forward speed of $1.40 \mathrm{~km} / \mathrm{h}$. Meanwhile, the minimum field efficiency of $76.32 \%$ was obtained with forward speed of $4.73 \mathrm{~km} / \mathrm{h}$. The slip percent of press wheel increased with increasing forward speed. The maximum slip of 15.91 $\%$ was obtained with forward speed of $4.73 \mathrm{~km} / \mathrm{h}$. Meanwhile the minimum slip of $12.43 \%$ was obtained with forward speed of $1.40 \mathrm{~km} / \mathrm{h}$.

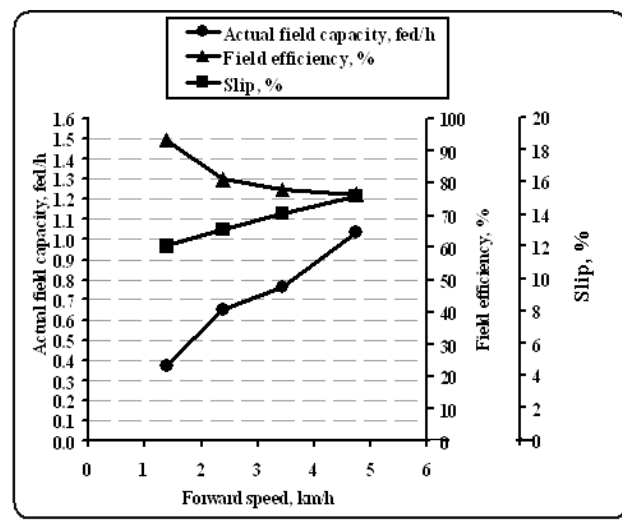

Fig. 11. Effect of forward speed on actual field capacity, field efficiency and slip percent.

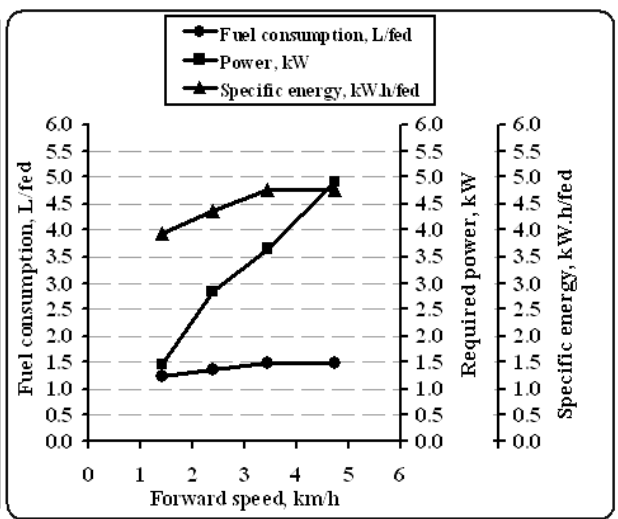

Fig. 12. Effect of forward speed on fuel consumption, required power and specific energy.

\section{Effect of forward speed on fuel consumption, required power and specific energy:}

Fig. 12. shows the effect of forward speed on fuel consumption, required power and specific energy. The maximum fuel consumption, required power and specific energy of $1.52 \mathrm{~L} / \mathrm{h}, 4.92 \mathrm{~kW}$ and $4.77 \mathrm{~kW} . \mathrm{h} /$ fed were obtained 
with forward speed of $4.73 \mathrm{~km} / \mathrm{h}$. Meanwhile the minimum values of 0.46 $\mathrm{L} / \mathrm{h}, 1.47 \mathrm{~kW}$ and $3.94 \mathrm{~kW} . \mathrm{h} / \mathrm{fed}$ were obtained at forward speed of 1.40 $\mathrm{km} / \mathrm{h}$.

\section{Cost of using the developed garlic cloves planter:}

Representative values of both operational cost and cost per unit of production versus machine forward speed are given in Figs. 13 and 14. Concerning the operational cost data obtained show that increasing forward speed from 1.40 to $4.73 \mathrm{~km} / \mathrm{h}$, decreased operational cost from 186.12 to 67.29 L.E/fed. The minimum planting-costs at optimum conditions (forward speed of $3.44 \mathrm{~km} / \mathrm{h}$ and cutoff clearance of $15 \mathrm{~mm}$ ) were $90.78 \mathrm{~L}$.E./fed and 15 L.E./Mg. Meanwhile, the maximum planting costs of 186.12 L.E./fed and 106.4 L.E./Mg were obtained at forward speed of $1.40 \mathrm{~km} / \mathrm{h}$ and cutoff clearance of zero $\mathrm{mm}$.

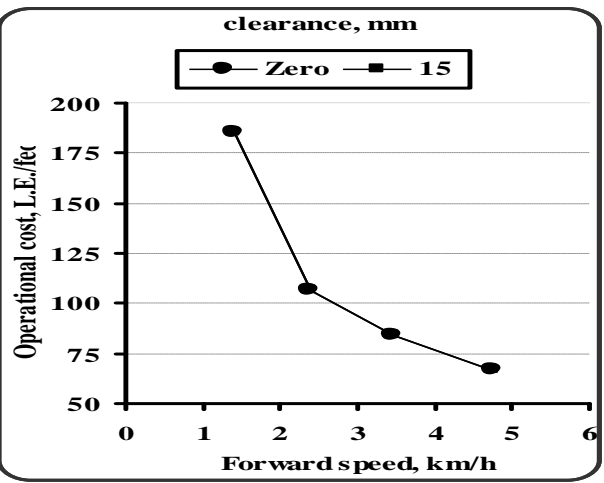

Fig. 13. Effect of forward speed and cutoff clearance on operational cost.

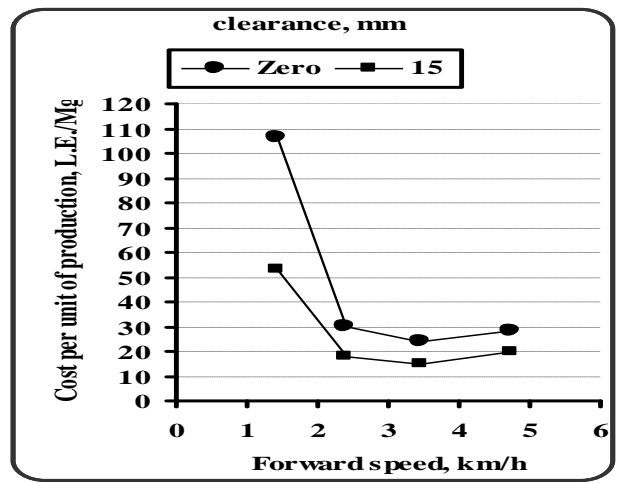

Fig. 14. Effect of forward speed and cutoff clearance on cost per unit of production.

\section{CONCLUSION}

The obtained results reveal that maximum crop yield of $7.2 \mathrm{Mg} / \mathrm{fed}$ and minimum planting cost of $15 \mathrm{~L} . \mathrm{E} / \mathrm{Mg}$ were achieved by using the developed garlic cloves planter for medium cloves size under the following operating conditions:

- Metering device speed of $20 \mathrm{rpm}$. 
- Agitator speed of $50 \mathrm{rpm}$.

- Forward speed of $3.44 \mathrm{~km} / \mathrm{h}$.

- Cutoff clearance of $15 \mathrm{~mm}$.

\section{REFERENCES}

Agric. Statistics Economic Affair Sector (2009): Agric. Statistics, Economical Issues Sector, Cairo, Egypt: 72-73.

Awady, M. N. (1992): Farm machines, Txtbk, Col. Ag., A. Shams U: 120 .

Awady, M. N. (1978): Tractor and farm machinery. Text book, Faculty of Agric., Ain-Shams Univ.: 164-167.

Awady, M. N; H. A. Abdel Mawla, I. Yehia and A. H. Mohamed (2000): Design of a drill metering-device for garlic cloves. $8^{\text {th }}$ Conf. Misr Soc. Agr. Eng., 25-26 Oct. 2000: 110-122.

Bakhtiari, M. R. and M. Loghavi (2009): Development and evaluation of an innovative garlic clove precision planter. J. Agric. Sci. Tec. Vol. 11: $125-136$.

El-Ashry, A. S. (2004): Modification of a potato planting machine to suit garlic crop. Misr J. Agric. Eng., 21(3): 657-668.

El-Sharabasy, M. M. A. and M.M. Ali (2011): Development and evaluation the planting unit of (gaspardo planter) suits for planting garlic gloves. Misr J. Ag. Eng. 28 (2): 282-301.

Harb, S. K. and H. A. Abdel-Mawla (1997): Development of a two row garlic planter. Misr J. Ag. Eng. 14 (1): 144-155.

Helmey, M. A; S. M. Gomaa and M. E. Badawy (2005): Modification and evaluation of garlic planter. Misr J. Agric. Eng., 22 (2): 663-687.

Hunt, D. R. (1983). Farm power and machinery management seedling machines eight edition: 102-111. 
Jarudchai, Y; K. Snoluch and B. Jiraporn (2002): Design and development of a garlic planter in Thailand. Agr. Eng. Dep., Fac. of Eng., King Mongkut's Ins. Tec. Lardkabang, Bangkok, Thailand 10520.: 1-10.

Mohsenin, N. N. (1986): Physical properties of plant and animal materials. Gordon and Breach Sc. Pub., N. Y.

\section{Rocha, F. E; C. De, T. Tsujimoto, S. Menezes, J. A. De and D. E. Castro} (1991): Garlic planters with two the drill type mechanism. Informe Agropecuario. 15: 16, 37-39.

Yehia, I. (1993): Design of a seed drill attached to a power tiller, M. Sc. Th., Fac. of Ag. Ain Shams U.: 57-140.

Yehia, I. (1997): Factors affecting the design of a feeding device for crop seeders, Ph. D. Th., Fac. of Ag. Ain Shams U.: 109-116.

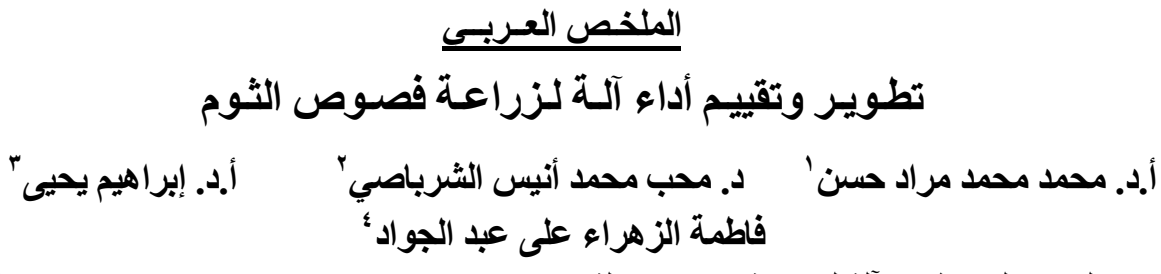

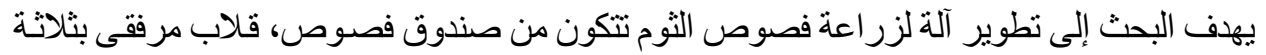

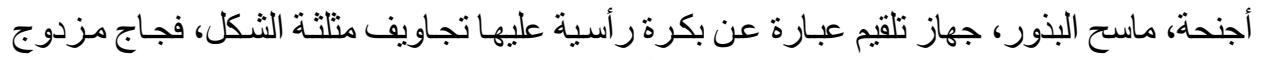

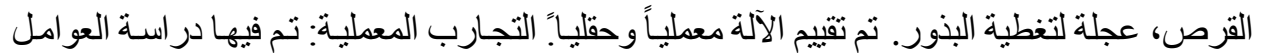

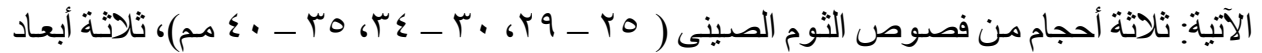

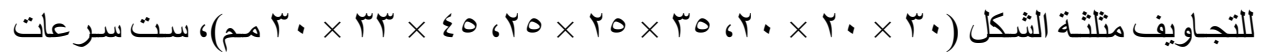

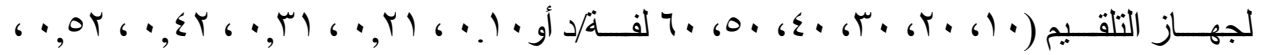

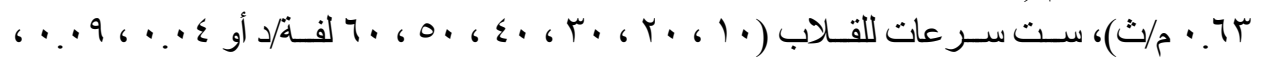

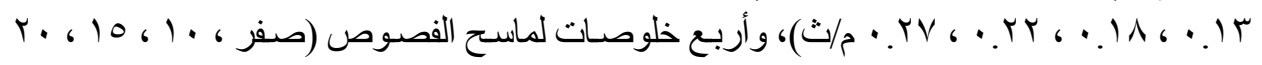

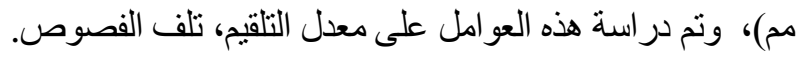

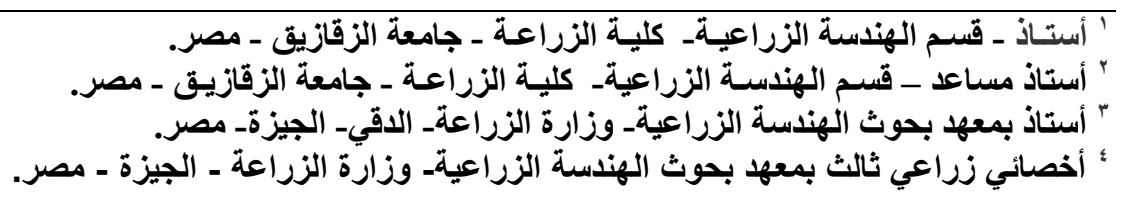




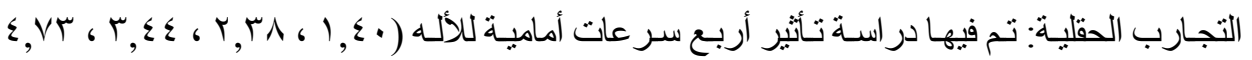

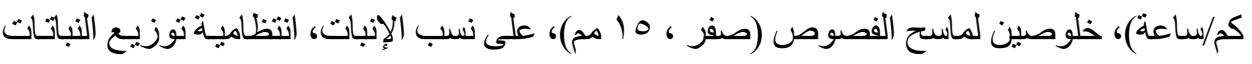

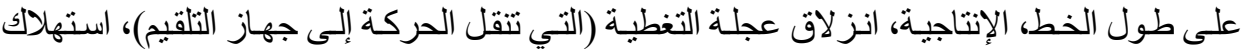

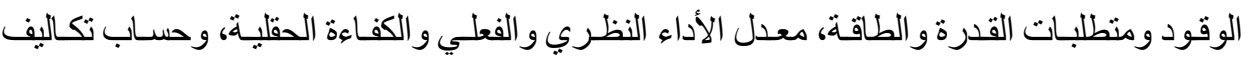

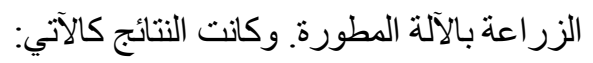

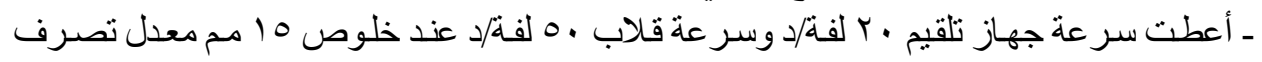

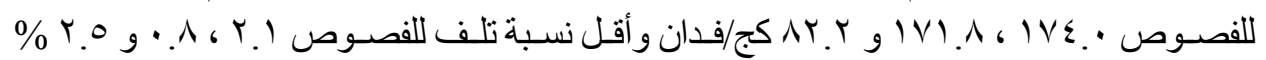
لفصوص الثوم الكبيرة والمتوسطة والصغيرة الحجم على الترتيب.

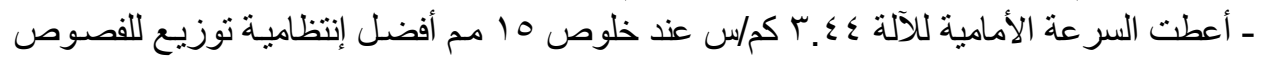

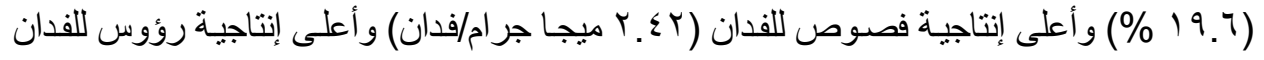

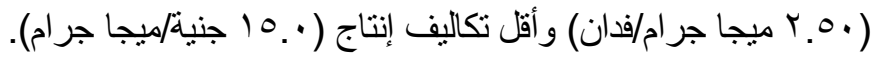

